\title{
Formulasi Arema Ralia (Aloe Vera Gel Mask With Extract Annredera Cordifolia) dan Tinjauan Aspek Kehalalannya
}

\author{
Achmad Maulana ${ }^{1}$ \\ Sintia Ainus Shofa ${ }^{2}$ \\ Universitas Islam Negeri (UIN) Sunan Kalijaga \\ Email : ${ }^{4} 4$ chmadmaulan4@gmail.com, ${ }^{2}$ sintiashofa@gmail.com
}

\begin{abstract}
Aloe vera gel mask is one of the most popular cosmetic products in the world. In Indonesian sales, locally made it by contain alcohol (ethanol). Argued that ethanol is a type of alcohol can irritate quickly for sensitive skin. Alcohol is often perceived by some people as non halal. Based on the problems, innovation of Aloe Vera Gel mask for sensitive skins are made, named Arema Ralia (Aloe Vera Gel Mask with Extract of Annredera Cordifolia), and need to assess its halalness. The formulation does not involve the addition of ethanol, because the main ingredient contains several antibacterial compounds such as lignin, saponins, flavonoids, alkaloids, polyphenols, phenols. Arema Ralia is made by mixing annredera cordifolia and aloe vera with additional ingredients such as glycerin, $\mathrm{NaCl}$, and water. The halal aspects of Arema Ralia need not be doubted. Alcohol content such as polyphenols and phenols in arema ralia is safe and beneficial for the skin. In addition, Polyphenols and phenols are not categorized as illicit alcohol according to the fatwa of MUI No. 11 of 2009, so that alcohol in Arema Ralia is halal.
\end{abstract}

\section{Keywords: Arema Ralia, Annredera Cordivolia, Halal, Aloe Vera, Mask}

\begin{abstract}
Abstrak
Aloe vera gel mask merupakan salah satu produk kosmetik yang cukup popular di dunia. Di Indonesia, masker aloe vera gel buatan lokal yang beredar luas di pasaran mengandung alkohol (etanol). Menurut Suryaatmaja (2016), alkohol jenis etanol dapat membuat kulit sensitif cepat iritasi. Alkohol sendiri sering dipersepsikan oleh sebagian orang sebagai bahan tak halal. Berdasarkan permasalahan tersebut dibuatlah inovasi masker aloe vera gel untuk kulit sensitif bernama Arema Ralia (Aloe Vera Gel Mask with Extract Annredera Cordifolia), dan perlu mengkaji kehalalannya. Formulasi masker ini tidak melibatkan penambahan etanol, karena dalam bahan utama Arema Ralia, yaitu lidah buaya dan binahong sudah terkandung senyawa antibakteri seperti lignin, saponin, flavonoid, alkaloid, polifenol, fenol, dan lain-lain (Manoi, 2009; Sudarto, 1997; Rachmawati, 2008). Metode pembuatannya dengan memodifikasi penelitian Kismaryanti (2007). Arema Ralia dibuat dengan mencampurkan daun binahong dan lidah buaya dengan penambahan bahan berupa gliserin, $\mathrm{NaCl}$ dan air. Aspek kehalalan Arema Ralia tidak perlu diragukan. Kandungan alkohol seperti polifenol dan fenol dalam arema ralia aman dan bermanfaat bagi kulit. Selain itu, Polifenol dan fenol bukan termasuk dikategorikan alkohol haram menurut fatwa MUI No. 11 tahun 2009, sehingga alkohol dalam Arema Ralia bersifat halal.
\end{abstract}

\section{Kata Kunci: Arema Ralia, Binahong, Halal, Lidah Buaya, Masker}

\section{Pendahuluan}

Gaya hidup halal bukan lagi hanya menjadi kewajiban, melainkan juga tren yang berkembang pesat. Pesatnya perkembangan gaya hidup halal terjadi di berbagai belahan bumi terkhusus negara dengan penduduk muslim. Konsep halal diberikan apresiasi yang tinggi karena 
produk halal dianggap sebagai produk yang lebih sehat, lebih bersih, dan lebih lezat (Burgmann, 2007). Fakta maupun penelitian ilmiah juga telah membuktikan bahwa produk halal ternyata lebih baik, aman dan sehat dibandingkan dengan produk haram. Hal ini sesuai dan telah diungkapkan oleh firman Allah SWT:

"... dan menghalalkan bagi mereka segala yang baik dan mengharamkan bagi mereka segala yang buruk ..." (QS. Al-A'raf [7]: 157).

Salah satu penerapan gaya hidup halal yang gencar dan perlu kecermatan dilakukan, terutama oleh kaum hawa adalah kosmetika. Pemilihan dan penggunaan kosmetika perlu kecermatan, karena tidak semua kosmetik yang beredar di pasaran berlabel halal. Bahkan tidak sekedar halal, sebaiknya juga thayyib atau baik dan aman. Hal ini diperkuat oleh fatwa MUI (Majelis Ulama Indonesia) nomor 26 tahun 2013, bahwasanya penggunaan kosmetika untuk kepentingan berhias hukumnya boleh dengan syarat bahan yang digunakan adalah halal dan suci, ditujukan untuk kepentingan yang dibolehkan secara syar'i, dan tidak membahayakan.

Salah satu produk kosmetik yang cukup populer yaitu Aloe Vera Gel atau masker gel lidah buaya. Masker ini dirasa mampu dan ampuh mengatasi beberapa masalah kulit wajah seperti jerawat, kasar, kusam, penuaan dini dan beberapa masalah dermatologis lain pada kulit wajah. Hal ini tidak terlepas dari kandungan senyawa yang ada dalam gel lidah buaya. Gel lidah buaya memiliki manfaat yang baik bagi kulit seperti melembabkan kulit, menghaluskan kulit, kulit tidak cepat kering, menghambat proses penipisan kulit, menjaga elastisitas kulit, menaikkan kandungan kolagen dermis, menghilangkan, jerawat, menyembuhkan luka dan menghilangkan noda hitam (Suryowidodo, 1988; Okyar, 2001; Sudarto, 1997).

Di Indonesia, masker Aloe Vera Gel buatan lokal yang beredar luas di pasaran masih mengandung alkohol (terutama etanol) dan turunannya, yang merupakan senyawa yang identik tidak halal. Dilansir dari situs Halalmui.org, menurut fatwa MUI tentang alkohol, tidak semua alkohol itu haram, tergantung pada sumber, penggunaan, sifat najis tidaknya. Meski begitu, kandungan alkohol dalam kosmetik bagi sebagian orang yang memiliki kulit sensitif dianggap dapat beresiko menyebabkan iritasi. Alkohol penyebab iritasi dan umum digunakan dalam kosmetik biasanya jenis etanol. Etanol mampu melarutkan minyak dan juga menguap dengan cepat sehingga membuat permukaan kulit jadi kering. Ini ideal untuk kulit yang sangat berminyak namun dapat membuat kulit sensitif cepat iritasi (Suryaatmaja, 2016). Maka dari itu banyak umat Islam terutama pelaku gaya hidup halal tidak hanya mempertimbangkan label halal, tapi juga thayyib, yang dalam hal ini adalah memilih kosmetik bebas etanol untuk mereka yang memiliki kulit sensitif. Oleh karena itu diperlukan langkah jitu dan inovasi yang tepat dalam menjawab tantangan tersebut. Tentunya menyediakan masker Aloe Vera Gel bebas alkohol jenis etanol, dan tentunya tidak berbahaya jika diaplikasikan ke kulit.

Umumnya, Alkohol dalam kosmetik berperan sebagai pengawet dan pelarut. Maka perlu memilih dan memilah bahan yang mampu menggantikan fungsi alkohol tersebut. Salah satu tanaman yang dirasa berpotensi sebagai pengawet adalah daun binahong. Tanaman binahong (Anredera cordifolia (Ten.) Steenis) merupakan salah satu jenis tanaman di Indonesia yang terbukti memiliki kandungan senyawa flavanoid, saponin dan triterpenoid yang berperan sebagai antibakteri (Lestari dkk, 2014). Jika melihat kandungan senyawa dan perannya sebagai antibakteri, bukan hal yang tidak mungkin binahong dapat digunakan sebagai pengawet.

Berdasarkan pemaparan di atas, kombinasi lidah buaya dan binahong berpotensi dimanfaatkan sebagai bahan baku pembuatan masker halal untuk kulit sensitif, yang selanjutnya 
produk masker ini disebut sebagai Arema Ralia (Aloe Vera Gel Mask with Extract Annredera Cordifolia). Maka perlu ditelaah dan diteliti lebih lanjut secara ilmiah, bahwa lidah buaya dan binahong berpotensi dapat diformulasikan sebagai masker. Dalam formulasi Arema Ralia tentu harus mempertimbangkan efektifitas bahan dan metode. Efektifitas menjadi hal yang penting, karena bahan yang digunakan harus bebas dari unsur alkohol jenis etanol, kalaupun mengandung etanol maka perlu metode yang tepat untuk menghilangkan etanol yang terkandung dan senyawa lain yang dinilai berbahaya. Selain itu, aspek halal menjadi poin penting dari Arema Ralia, karena pada dasarnya Arema Ralia merupakan bentuk inovasi produk kosmetik halal.

Berdasarkan latar belakang yang dijelaskan di atas, rumusan masalah penelitian ini sebagai berikut:

1. Bagaimana formulasi Arema Ralia?

2. Bagaimana Arema Ralia ditinjau berdasarkan aspek halal?

Adapun tujuan penulisan karya tulis ini yaitu:

1. Memahami dan mengetahui formulasi Arema Ralia.

2. Menganalisis berdasarkan aspek halal terhadap Arema Ralia.

Manfaat penulisan karya tulis ini yaitu:

1. Teoritis, yaitu memberikan khasanah pengetahuan baru, serta dapat dijadikan rujukan atau referensi untuk penelitian lanjutan yang relevan.

2. Praktis, yakni memberikan alternatif implementatif yang dapat diterapkan dalam praktik pembuatan masker halal untuk kulit sensitif.

\section{Metode Penulisan}

Jenis penulisan karya tulis ini eksploratif yang bersifat kualitatif-deskriptif dan bercorak research, yaitu penelitian yang dilakukan dalam rangka memperluas dan memperdalam pengetahuan secara teoritis. Adapun tujuannya. Mengembangkan suatu disiplin ilmu atau pengembangan disiplin-teoritik. Sementara itu, tahapan penulisannya sebagai berikut:

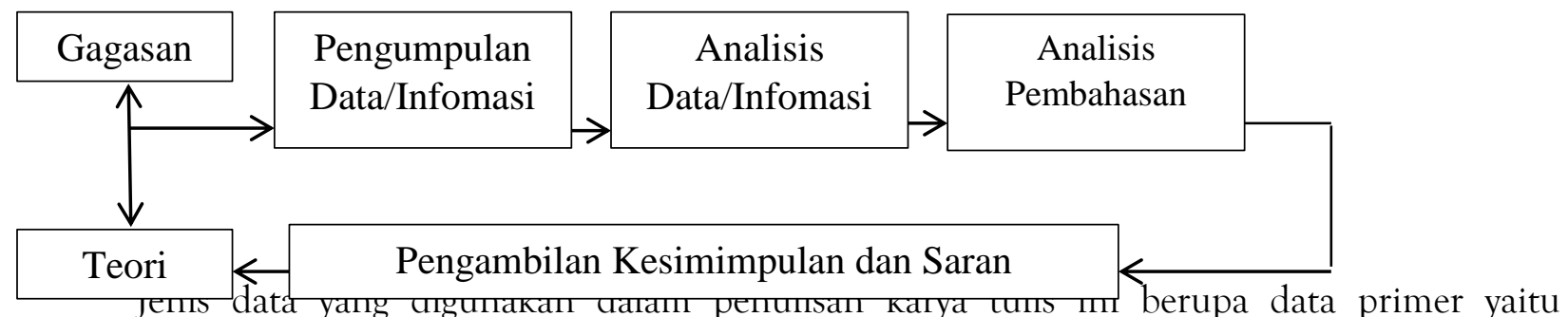
eksperimen, dan data sekunder yaitu kajian pustaka. Dalam pengumpulan data memakai metode wawancara, penulis wawancara kepada dosen atau ahli bidang kimia. Serta metode eksperimen dan kajian pustaka yang dikuatkan dengan penelitian yang relevan. Analisis data dalam penulisan ini menggunakan model contest analysis dan eksplorasi, yaitu suatu analisis tekstual dalam studi pustaka melalui investigasi terhadap isi dalam berbagai literatur dan penelitian yang relevan.

\section{Metode Penelitian}

Penulisan karya tulis ilmiah ini, penulis menggunakan jenis penelitian pengembangan $\mathrm{RnD}$ (Research and Development) dan kajian pustaka. Alat yang digunakan pada percobaan ini adalah pisau, gelas ukur $100 \mathrm{ml}$, pengaduk, gekas beker, blender, penyaring, baskom, gelas arloji, sendok sungu, hotplate dan termometer. Bahan yang digunakan pada penelitian ini adalah daun lidah buaya, daun binahong, gliserin, garam dan akuades. 


\section{Prosedur Kerja}

Ekstraksi daun binahong

Daun binahong dikeringkan. Daun binahong ditambahkan etil asetat dan dimaserasi (direndam) selama 24 jam pada suhu kamar. Hasil maserasi yang didapat kemudian disaring menggunakan corong buchner hingga fitrat dan residu terpisah.

Pembuatan masker gel

Pembuatan masker yaitu mengambil gel yang terkandung dalam lidah buaya, yaitu dengan cara menghaluskan gel lidah buaya menggunakan blender kemudian gel lidah buaya dimasukkan ke dalam gelas beker. Gel lidah buaya ditambahkan dengan ekstraksi daun binahong dan akuades, aduk secara berkala hingga homogen. Campuran dipanaskan hingga suhu mencapai 70-80 ${ }^{\circ} \mathrm{C}$. Gliserin dan garam ditambahkan kedalam adonan gel, aduk hingga merata sampai didapatkan tekstur yang kental.

\section{Hasil Dan Pembahasan}

Arema Ralia diformulasi menggunakan bahan baku berupa gel lidah buaya dan ekstraksi daun binahong. Prosedur pembuatan masker Arema Ralia bagian pembuatan gel lidah buaya merupakan modifikasi dari pembuatan gel lidah buaya sebagai pengawet tomat dari metode yang telah dilakukan oleh Kismaryanti (2007). Metode ini dilakukan secara sederhana namun tetap mempertahankan mutu serta senyawa aktif yang terdapat pada gel lidah buaya. Tahapan yang dilakukan untuk pembuatan masker arema adalah proses homogenisasi antara ekstrak daun binahong dan gel lidah buaya.

Formulasi Arema Ralia tidak membutuhkan etanol yang merupakan senyawa yang sering dijumpai pada beberapa produk kosmetik sebagai pengawet dan anti bakteri. Hal ini karena lidah buaya dan binahong mengandung senyawa aktif yang dapat menggantikan fungsi etanol sebagai anti bakteri dan pengawet. Secara lebih rinci, kandungan senyawa aktif lidah buaya ditunjukkan pada Tabel 1. Sementara kandungan senyawa aktif pada binahong ditunjukkan pada Tabel 2. Kandungan senyawa aktif tersebut tidak hanya berfungsi sebagai anti bakteri saja, melainkan memiliki fungsi dan manfaat lain yang bersifat sebagai skin care.

Tabel 1. Komponen Senyawa Aktif pada Lidah Buaya

\begin{tabular}{|l|l|}
\hline \multicolumn{1}{|c|}{ Zat } & \multicolumn{1}{c|}{ Kegunaan } \\
\hline Acemannan & $\begin{array}{l}\text { Anti-inflammatory, wound healing, } \\
\text { anti-kanker, anti-virus, UV sunburn }\end{array}$ \\
\hline Glikoprotein & Anti-diabetes, anti-kanker \\
\hline Aloe emodin & Anti-kanker, anti-oksidan, anti-mikroba \\
\hline Lectin & $\begin{array}{l}\text { Anti-inflammatory, wound healing, } \\
\text { anti-kanker }\end{array}$ \\
\hline $\begin{array}{l}\text { Aloin (Barbalain) dan komponen } \\
\text { fenolik }\end{array}$ & Anti-mikroba, anti-oksidan \\
\hline Alomicin & Anti kanker \\
\hline
\end{tabular}

(Reynolds dan Dweck, 1999). 
Tabel 2. Komponen Senyawa Aktif pada Binahong

\begin{tabular}{|l|l|}
\hline \multicolumn{1}{|c|}{ Zat } & \multicolumn{1}{|c|}{ Kegunaan } \\
\hline Asam oleanolik & $\begin{array}{l}\text { Anti Inflamasi, antioksida, mencegah } \\
\text { masuknya racun ke dalam sel dan } \\
\text { meningkatkan sistem pertahanan sel. }\end{array}$ \\
\hline Minyak atsiri & $\begin{array}{l}\text { Bahan antiseptik internal dan eksternal, } \\
\text { bahan analgesik, hemolik dan stimulan. }\end{array}$ \\
\hline Saponin & $\begin{array}{l}\text { Mempunyai kemampuan } \\
\text { membersihkan dan bersidat antiseptik, } \\
\text { bahan pencuci yang sangat baik }\end{array}$ \\
\hline Polifenol & Antibakteri \\
\hline Alkaloid & $\begin{array}{l}\text { Menaikkan tekanan darah, mengurangi } \\
\text { rasa sakit dan antimokroba }\end{array}$ \\
\hline
\end{tabular}

(Harborner, 1987; Guenther, 1987; Makkar, 2005; Furnawanthi,2003).

Pembuatan ekstrak daun binahong dilakukan dengan metode maserasi. Metode ini memiliki keuntungan yaitu tidak adanya pemanasan sehingga senyawa labil tidak gampang rusak atau hilang karena adanya panas, cara pengerjaannya mudah dan peralatan yang digunakan sederhana (Anonim, 1986). Pelarut yang digunakan pada proses maserasi binahong adalah asetil asetat. Asetil asetat dipilih karena memiliki sifat semipolar, tidak higroskopis, tidak beracun dan dapat larut dengan senyawa flavonoid dan fenol. Maserasi (perendaman) dilakukan selama 24 jam, hal ini didasarkan pada Wardhani (2012), dimana menurutnya perendaman 24 jam bertujuan untuk mengendapkan senyawa-senyawa yang tidak diinginkan saat dilakukan penyaringan.

Pembuatan gel lidah buaya dimulai dengan pemilihan pelepah daun lidah buaya berdasarkan penampakan fisiknya, diantaranya tingkat kematangan daun ditandai dengan daun yang sudah berwarna coklat, ukuran daun yang sesuai dan tidak adanya kotoran atau penyakit yang menempel pada daun lidah buaya. Setelah daun lidah baya dipilih sesuai dengan kriteria, daun lidah buaya kemudian dicuci untuk menghilangkan kotoran yang menempel dan direndam dengan larutan dengan asam sitrat. Perendam dengan asam sitrat bertujuan untuk menghilangkan kotoran-kotoran yang menempel selain itu, asam sitrat berfungsi sebagai desinfektan yang mampu mencegah tumbuhnya bakteri. Setelah direndam, daun lidah buaya dibilas dengan akuades untuk menghilangkan asam sitrat yang menempel. Kemudian bagian pangkal ujung, sisi daun yang berduri dan semua kulit daun lidah buaya dibuang. Pembuangan bagian-bagian itu bertujuan untuk menghilangkan senyawa yellow sap (senyawa antharaquinone beserta turunannya). Namun, biasanya yellow sap masih belum bersih sehingga dapat dilakukan pembilasan dengan akuades agar yellow sap dapat hilang. Yellow sap penting untuk dihilangkan karena jika gel terkontaminasi dengan yellow sap dapat mengubah warna gel lidah buaya, bau tidak sedap dan mempengaruhi umur simpan dari gel tersebut. Setelah itu, gel lidah buaya yang dihasilkan dipotong dan dihancurkan menggunakan blender hingga tekstur gel lidah buaya benar-benar hancur (Krismaryanti, 2007).

Pembuatan masker dilakukan dengan mencampurkan gel lidah buaya dengan ekstrak daun binahong pada suhu $60^{\circ} \mathrm{C}$. Pemanasan dilakukan untuk menghilangkan flavonoid yang termasuk 
fenol. Kemudian campuran ditambahkan dengan gliserin. Penambahan gliserin bertujuan untuk humaktan (pelembab kulit). Selain ditambahkan gliserin, campuran ditambahkan dengan garam $(\mathrm{NaCl})$ secukupnya. Penambahan garam bertujuan sebagai gelling agent, mengangkat sel-sel kulit mati mengeluarkan toksin dari kulit dan mengatasi kulit yang kasar (Surtiningsih, 2005). Campuran diaduk hingga homogen dan suhu dijaga $60^{\circ} \mathrm{C}$. Suhu dijaga $60{ }^{\circ} \mathrm{C}$ bertujuan agar senyawa yang terkandung dalam daun binahong atau gel lidah buaya tidak rusak karena pemanasan.

Arema Ralia disimpan menggunakan pembungkus berbahan Polyethylenen Perephtalate (PET). Menurut Mujiarto (2005), Polyethylene Perephtalate memiliki sifat kuat, tidak beracun, permeabilitas terhadap gas, memiliki daya serap uap air dan air yang rendah. Polyethylene Perephtalate biasa digunakan untuk kemasan sirup, saus, selai, dan shampo. Sehingga, Polyethylene Perephtalate juga dapat digunakan untuk membungkus masker Arema Relia agar terjaga dari interaksi air dan gas lainnya.

\section{Aspek Kehalalan}

Halal adalah sebuah konsep aturan prinsip agama Islam, yang digunakan untuk menyatakan bahwa sesuatu hal diizinkan atau dilarang untuk dikonsumsi oleh Muslim dengan dasar dari al-Qur'an, hadist, atau ijtihad (kesepakatan ulama) (Salehudin, 2010). Menurut Imam alGhazali, Sesuatu yang halal itu selalu mengandung fadhilah (keutamaan) dan segala sesuatu yang haram itu mengandung kemudlaratan (tercela/buruk). Oleh sebab itulah maka segala yang haram itu dilarang dan segala yang halal itu dianjurkan (Supeno, 2014).

Halal menjadi aspek yang sangat fundamental bagi umat Islam karena halal merupakan salah satu wujud manivestasi. Karena itu, dalam berbagai hal perlu mendasarkan diri pada aspek halal, termasuk bidang kosmetik. Sebagai produk yang dibuat untuk menunjang gaya hidup halal, maka Arema Ralia perlu dilakukan peninjauan atau analisis untuk mengetahui kehalalannya.

Standar kehalalan produk kosmetika dan penggunaannya, diantaranya ialah bahan yang digunakan halal dan suci, tidak membahayakan, tidak mengandung najis, tidak mengandung zat atau senyawa yang berasal dari babi, dan tidak berasal dari mikroba hasil rekayasa genetika yang melibatkan gen babi atau gen manusia (MUI, 2013). Adapun Arema Ralia yang diformulasikan berbahan dasar lidah buaya, binahong, dengan bahan pelengkap berupa gliserin, garam $(\mathrm{NaCl})$ dan akuades. Komposisi bahan Arema Ralia berasal dari bahan alami yang tidak berbahaya, justru memiliki manfaat yang mampu merawat kulit. Bahan-bahan tersebut sebelumnya dicuci atau dipastikan terhindar dari kontaminasi najis, sehingga dapat dikategorikan bahan halal. Selain itu, pada proses formulasi Arema Ralia tidak melibatkan metode, proses dan reaksi berbahaya.

Salah satu bahan yang sering dijumpai pada produk kosmetik namun diragukan kehalalannya ialah alkohol. Sikap ini muncul karena didasarkan pada hadits Nabi SAW:

"Dari Ibnu 'Umar, bahwasanya Rasulullah SAW bersabda, "Setiap (minuman) yang memabukkan itu khamr, dan setiap (minuman) yang memabukkan itu haram". [HR. Muslim juz 3, hal. 1587].

Menurut fatwa MUI (2009), tidak semua jenis alkohol hukumnya haram. Penggunaan alkohol/etanol hasil industri khamr untuk produk makanan, minuman, kosmetika, dan obatobatan, hukumnya haram. Menurut Wakil Direktur LPPOM-MUI, Ir. Muti Arintawati M.Si., hanya kosmetika yang mengandung alkohol jenis ethyl alcohol (etanol dan methylated spirit) yang dinilai haram. Jenis ini banyak digunakan pada lotion aftershave maupun parfum wanita. Zat ini dapat diserap oleh kulit. Sedangkan, jenis cetyl alkohol dan cetearyl alkohol dikategorikan halal. Cetyl 
adalah alkohol yang terdiri atas molekul berantai panjang. Alkohol ini berbentuk padat sehingga tidak dapat diminum dan tidak dapat diserap kulit. Bahan ini juga tidak beracun. Sedangkan, cetearyl alkohol banyak terdapat pada kosmetik dan skin care.

Arema Ralia tidak melibatkan penambahan alkohol terutama etanol yang sering dijumpai pada produk kosmetik untuk mengawetkan dan melarutkan senyawa organik. Kandungan alkohol pada Arema Ralia hanya berasal dari lidah buaya dan binahong. Kandungan alkoholnya yaitu polifenol dan fenol (Manoi, 2009). Polifenol dan fenol tentu halal jika meninjau dari fatwa MUI No. 11 tahun 2009. Fenolat memiliki berbagai aktivitas, misalnya antibakteri, antijamur, antioksidan, sedatif, dan lain-lain (Saifudin dkk., 2011). Sehingga dapat dikatakan bahwa Arema Ralia bersifat halal, bahkan thayyib karena bebas etanol dengan kandungan turunan alkohol sangat sedikit pula sehingga cocok untuk kulit sensitif.

\section{Kesimpulan}

Berdasarkan uraian di atas dapat disimpulkan; Formulasi Arema dibuat dengan memodifikasi penelitian Andiny Kismaryanti (2007) tentang pembuatan gel lidah buaya sebagai pengawet tomat. Pembuatan arema ralia dibuat dengan mencampurkan daun binahong dan lidah buaya dengan menambahkan bahan tambahan seperti gliserin, $\mathrm{NaCl}$ dan akuades.

Aspek kehalalan Arema Ralia tidak perlu diragukan. Kadungan alkohol seperti polifenol dan fenol dalam arema ralia aman bagi tubuh dan bermanfaat bagi tubuh. Selain itu, Polifenol dan fenol bukan termasuk dikategorikan alkohol haram menurut fatwa MUI No. 11 tahun 2009, sehingga alkohol dalam Arema Ralia bersifat halal.

\section{Saran}

Berdasarkan kesimpulan di atas, bahwa Arema Ralia merupakan produk kosmetik berupa masker yang aman bagi para pelaku gaya hidup halal terutama wanita muslim. Bahan yang terkandungan dalam Arema Ralia merupakan bahan yang tidak berbahaya dan halal. Sehingga, diharapkan Arema Ralia dapat diteliti lebih dalam, dan diproduksi massal untuk dijadikan salah satu solusi produk kosmetik yang aman dan halal. Selain itu, dihimbau masyarakat lebih berhatihati dalam memilih produk kosmetik yang halal.

\section{DAFTAR PUSTAKA}

Anonim. 1986. Sediaan Galenik. Jakarta: Departemen Kesehatan Republik Indonesia.

Fatwa Majelis Ulama Indonesia Nomor 26 Tahun 2013 tentang Standar Kehalalan Produk Kosmetika dan Penggunaannya. https://mui-jateng.or.id/standar-kehalalan-produk-kosmetikadan-penggunaannya, diakses pada 26 Maret 2019.

Furnawanthi, Irni. 2002. Khasiat dan Manfaat Lidah Buaya. Depok: Agro Media Pustaka.

Guenther, E. 1987. Minyak Atsiri Jilid I. Jakarta: UI Press.

Harborner, J. B. 1987. Metode Fitokimia Penuntun Cara Modern Menganalisis Tumbuhan Edisi Kedua. Diterjemahkan: Kosasih Padmawinata dan Iwang Soedira. Bandung: ITB Press.

Kismaryanti, Andiniy. 2007. Aplikasi Gel Lidah Buaya (Aloe vera L.) sebagai Edible Coating pada Pengawetan Tomat. Skripsi. Bogor: IPB. 
Lestari T., dkk. 2014. Kajian Aktivitas Penyembuhan Luka dan Antibakteri Binahong (Anredera cordifolia (Ten.) Steenis, Pegagan (Centella asiatica (L.) Urban) serta Kombinasinya Terhadap Bakteri Staphylococcus aureus dan Pseudomonas aeruginosa dari Pasien Luka Kaki Diabetes. Bionatura Jurnal Ilmu-ilmu Hayati dan Fisik. 16(2):78-79.

Makkar, H. P. S. 2005. Quantification of Tanins in Tree and Shrub Foliage. A Laboratory Manual. Dordrecht: Kluwer Academic Publisher.

Manoi, F. 2009. Binahong Anrederacordifolia (Tenore Steen) sebagai Obat. Jurnal Warta Penelitiandan Pengembangan Tanaman Industri.

Mujiarto, Imam. 2005. Sifat dan Karakteristik Material Plastik dan Bahan Aditif. Traksi. 3(2): 65.

Okyar, A., dkk. 2001. Effect of Aloe Vera Leaves on Blood Glucose Level in Type I and Type II Diabetic Rat Models. Phytoter Res. 15(2): 157-161.

Rachmawati, S. 2008. Study Macroscopic dan Skrining Fitokimia Daun Anredera Cordifolia (Ten) Steenis. Surabaya: Universitas Airlangga.

Reynolds, T. dan Dweck A. C. 1999. Aloe Vera Leaf Gel : A Review Update. Journal of Ethnopharmacology. 68(1-3): 3-37.

Saifudin, A., dkk. 2011. Standarisasi Bahan Obat Alam. Yogyakarta: Graha Ilmu.

Salehudin, I. 2010. Halal Literacy: A Concept Exploration and Measurement Validation. ASEAN Marketing Journal. 2(1): 1-12.

Sudarto, Yudo. 1997. Lidah Buaya. Yogyakarta: Kanisius.

Supeno, Bambang I. 2014. Pandangan Imam Al-Ghazali Tentang Halal dan Haram. Surabaya: Insan Amanah.

Surtiningsih. 2005. Cantik dengan Bahan Alami, Cara Mudah, Murah dan Aman untuk Mempercantik Kulit. Jakarta: Elex Media Computindo.

Suryaatmaja, Ardi. 2016. Alkohol dalam Produk Kecantikan, Baik atau Buruk. https://m.liputan6.com/fashion-beauty/read/2554694/alkohol-dalam-produk-kecantikanbaik-atau-buruk, diakses pada 18 Maret 2019.

Suryowidodo, C. W. 1988. Lidah Buaya (Aloe Vera Linn.) sebagai Bahan Baku Industri. Journal AgroBased Industri. 5(2): 66-71.

Wardhani, Lilies Kusuma. 2012. Uji Aktivitas Antibakteri Ekstrak Etil Asetat Daun Binahong (Anredera Scandens(L.) Moq.) terhadap Shigella flexneri Beserta Profil Kromatografi Lapis Tipis. Jurnal Ilmiah Kefarmasian. 2 (1): 1- 6.

Burgmann, Tamsyn. 2007. Halal Flexes its Marketing Muscle. https://www.thestar.com/business/article/238551, diakses pada 25 Maret 2019. 
Fatwa Majelis Ulama Indonesia Nomor 11 Tahun 2009 tentang Alkohol. https://www.halalmui.org/images/stories/Fatwa/fatwaalkohol.pdf, diakses pada 25 Maret 2019. 